\title{
AT THE ROOTS OF MELANCHOLY: IS GREEK MEDICINE MELANCHOLIC?
}

In a colloquium on melancholy in the modern world, this paper may well be considered out of place. However, I am very grateful to the organisers for welcoming these thoughts on the origins of melancholy and the melancholic temperament in Greek medicine. They may be helpful in showing the difference(s) between ancient and modern understandings of melancholy. In any case, they provide a good occasion for a critical examination of the way in which the relevant concepts and technical terms are established and perpetuated in the medical tradition, quite independently from the philosophical tradition. My paper will also make use of new Greek medical texts, or translations from Greek, which contribute to what we know about the melancholic temperament in Late Antiquity and Byzantium.

I will begin with the Hippocratic Corpus, the collection of medical writings attributed to Hippocrates, the great fifth century вС Greek doctor, comprising some sixty treatises that the Renaissance knew firstly in Latin, and then in Greek, from $15^{25}-15^{26}$ onwards. This is an appropriate beginning, because it shows that the three fundamental notions of black bile, melancholy and the melancholic temperament, whilst being related, did not originate at the same time and were not necessarily used in one and the same context.

The Nature of Man is the only treatise from the Hippocratic Corpus that can be attributed with any certainty to an author, Polybus, Hippocrates' student and son-in-law. It is also considered, with some justification, to be the foundation stone of the history of black bile, the melancholic temperament and melancholy in the medical tradition. However, we must refine and clarify the place and role of this treatise concerning these three concepts.

The treatise is undoubtedly the first text to present clearly the theory of the four humours innate in man: blood, phlegm, yellow bile and black bile. Let us recall its famous definition of the nature of man, of health and of illness: 
The body of man contains blood, phlegm, yellow bile and black bile. This is what constitutes the nature of the body; this is the cause of disease or good health. ${ }^{1}$

Out of two varieties of bile, the author has created two different humours, and in this sense, we can say that he has invented black bile. By means of this differentiation, the medical writer created a four-fold humoral theory defining the nature of man, a theory that was indirectly influenced by Empedoclean philosophy, despite the author's desire to distinguish, within his own definition, the four principles from the four elements of the universe (air, fire, water, earth). In this way, the author laid down fundamental tenets that would fully develop in later western Greek and Latin medicine, and then in medieval thought.

However, we must carefully distinguish between what we find in the treatise Nature of Man and what we do not find there. The Hippocratic writer makes a clear connection between the natural cycle of the humours and the cycle of the seasons, each of the four humours predominating in each of the four seasons, according to a clear correspondence between the elemental qualities defining each humour and each season. Black bile (melaina cholê), which is defined by two of the four elemental qualities (cold and dry), predominates in autumn, a season defined by the same elemental qualities. $^{2}$

Humours are further connected with ages. When discussing quartan fever, the author indicates in passing that black bile dominates in men aged between twenty-five and forty-two years old, corresponding to maturity, i.e. the autumn of life. ${ }^{3}$ This suggests a relationship between the four humours with the four ages of life, although the theory is not as systematically discussed as the relationship with the seasons.

However, no physiological relationship is established between the humours and the bodily organs. Thus black bile is never associated with the

${ }^{1}$ Hippocrates, Nature of Man, ch. 4, ed. Jouanna CMG I 1, $3^{2}, 2002$, p. 173. On the history of the theory of the four humours, the work of E. Schöner, Das Viererschema in der antiken Humoralpathologie, in Sudhoffs Archiv, Beiheft 4, Wiesbaden, 1964, remains fundamental. Simultaneously, a monumental study was published by R. Klibansky, E. Panofsky and F. Saxl, Saturn and Melancholy. Studies in the History of Natural Science, Religion and Art, New York, 1964, which extends from antiquity to Dürer. It includes a first chapter on "Melancholy in the Physiological Literature of the Ancients," with clear comparisons of the texts that present the theory of the four temperaments. This study was praised and used by H. Flashar, Melancholie und Melancholiker in den medizinischen Theorien der Antike, Berlin, 1966. It was preceded by a previous work by Panofsky / Saxl on Dürers "Melancolia I", Leipzig, 1923.

2 Hippocrates, Nature of Man, ch. 7, ed. Jouanna, p. 182,3f.

3 Hippocrates, Nature of Man, ch. 15, ed. Jouanna, p. 204,15-19. 
spleen, an organ that is never mentioned in Nature of Man. ${ }^{4}$ Above all, there is not the slightest trace in the treatise of a theory of the four physical or moral temperaments corresponding with the predominance of each of the four humours. Thus, although the author of Nature of Man is, as we have just seen, the inventor of black bile, he is not the inventor of the melancholic temperament. Of course, there are a few passages in the Hippocratic Corpus where the melancholic constitution (which is dominated by black bile) is distinguished from the 'choleric' constitution (which is dominated by yellow bile), but we find no systematic discussion of the four temperaments defined in physical and moral terms. ${ }^{5}$ In this sense, the theory of the four humours in Nature of Man is a stepping stone for a theory of the four temperaments that would only appear much later, in an elaborated form, in a post-Galenic phase of Greek medicine, to which we shall return below.

What about melancholy itself? Although it might seem paradoxical, there is no mention in the Nature of Man of the affliction called melancholy (melancholiê). ${ }^{6}$ This does not mean that the author does not discuss pathological cases caused by an excess of black bile, and he describes how illnesses caused by black bile predominate in autumn and cease in spring. ${ }^{7}$ Yet we do

\footnotetext{
${ }^{4}$ When was the connection between the spleen and black bile made for the first time? The association between the two is attested in texts discussing the four temperaments. See, for example, the work On the Constitution of the Universe and of Man, ed. Ideler I, p. 303,23 f. ("black bile is in the spleen"). In Galen, a relationship between black bile and the spleen is already taken for granted. See, for example, On the Natural Faculties 1, ch. 13, 2.40,9 K. (criticising Asclepiades on black bile and the spleen); Theriac to Piso, 14.277,4 K. (medically removing black bile from the spleen); Commentary on Hippocrates' Aphorisms, 17 B.659,15 (the large size of the spleen in illnesses caused by black bile); but the spleen is not yet the seat of black bile in the way in which the gall bladder is the seat of yellow bile; see On Black Bile, ch. 8, 9, ed. W. de Boer 93, 16-18.

5 The passage that comes closest to a theory of the four temperaments is Epidemics 3.14, ed. Kuehlewein $1.231,15(=3.98,4$ L.), where three temperaments are distinguished: 1. Melancholics and sanguinics; 2. Phlegmatics; 3 . Cholerics. Thus there are only three temperaments here, and they are considered only from a physical point of view. On the distinction between melancholics and cholerics, see also Regimen in Acute Diseases, ch. 16, $2.358,1 \mathrm{f}$. L. (ch. 61, Joly CUF, 63,10 f.), where we read that the acidity of vinegar sits better in those in whom bitter bile dominates (pikrocholoisi) than those in whom black bile dominates (melancholoisi). In Affections, ch. 36, ed. Potter 58,11, there is a distinction between the bilious, whom one must give medicines in order to evacuate bile, and melancholics, whom one must give medicines in order to evacuate black bile; but the passage is suppressed by Artelt and Potter, since it contradicts the bi-humoral theory (phlegm, bile) of the treatise (cf. ch. 1 and ch. 37).

${ }_{6}$ The author knows the adjective 'melancholic'. Used once in the neuter (ch. 15, ed. Jouanna, 204,15 melancholikon), it is the exact synonym of black bile. Latin atrabilis corresponds to the melancholic humour.

7 Hippocrates, Nature of Man, ch. 8, ed. Jouanna, 186,17-19.
} 
not find any systematic enumeration of these illnesses. It is only in passing that he gives a clear example of a complaint caused by black bile: quartan fever. ${ }^{8}$

In short, whilst the Nature of Man has invented black bile within the framework of the theory of the four humours, it does not discuss the theory of melancholic temperament, nor does the treatise mention the complaint called 'melancholy'. However, this does not mean that the author was not aware of it, since the illness was attested in a slightly older Hippocratic treatise.

The oldest text where melancholy is attested is the Hippocratic treatise Airs, Waters, Places, which could well be the work of Hippocrates himself, although this cannot be proven beyond doubt. Less theoretical than Nature of Man, the treatise Airs, Waters, Places is aimed at practitioners, and it enumerates the illnesses that are likely to occur according to the orientation of places or the succession of seasons. Melancholy is mentioned here in the discussion of climate. The author states that if we take the example of a year where the summer and start of the autumn are characterised by dryness with a northerly wind, the climate favours phlegmatic constitutions, but is very harsh to bilious ones. He then enumerates the illnesses that arise, ending with melancholy:

This period is most inimical to the bilious, for they become too dry, and ophthalmia of a dry nature supervenes, acute and long-lasting fevers, and in some cases melancholy (melancholiai). For the wettest and most watery part of the bile is consumed, whilst the thickest and most acrid portion is left; the same applies to the blood, when these diseases occur amongst the bilious. ${ }^{9}$

This passage is of crucial importance because it is the first text in Greek literature where the word melancholiê is attested. Linguistically speaking, this feminine noun ending in -iê is derived from the composite adjective melancholos, attested once in the ancient period in a poetic text, Sophocles' Trachiniae, concerning the poison of the Lernaean hydra. The adjective means etymologically 'of black or dark bile'. ${ }^{10}$ The noun melancholiê undoubtedly

${ }^{8}$ In a separate discussion of fevers, which are also four in number (ch. 15, ed. Jouanna, p. 202,10f.), the author of Nature of Man attributes quartan fever to black bile and explains the tenacity of this fever by the nature of black bile, the most viscous of the body's humours (ibid. 204,8-14).

${ }^{9}$ Hippocrates, Airs, Waters, Places, ch. 10, ed. Jouanna, CUF, 1996, pp. 217,5-218,2; Transl. C.D. Adams, modified.

${ }^{10}$ Sophocles, Trachiniae, v. 573 f. ( $\mu \varepsilon \lambda \alpha \gamma \chi \dot{\lambda} \lambda$ ov... ioús). The adjective does not necessarily presuppose the existence of black bile as a humour, but can be understood as referring to a 
refers to an illness and not to anything else. It is surprising that the medical writer mentions the illness without listing any symptom, which shows that it was well-known during his time. Thus, the author of Airs, Waters, Places did not invent melancholy in the sense in which the author of Nature ofMan invented black bile as a humour in its own right. Melancholy originated in Greek medicine at a stage prior to Hippocrates, and its origin will remain hidden in the shadows of Greek medical prehistory.

Thus, the existence of the illness pre-dates the existence of black bile as an independent humour. In fact, the explanations given in Airs, Waters, Places to account for melancholy are not yet situated in a theory in which black bile is found as an innate humour. It is the pathological change of bile that explains melancholy, whilst other illnesses affect the bilious temperaments due to a particularly dry climate. They originate from a drying and thickening of bile and blood.

From these two early Hippocratic treatises, we can see that there were two possible models of humoral explanation for melancholy by means of bile: either a degradation of bile, which is transformed into black bile by an excess of dryness, or black bile directly, an innate humour. These two different options contained in the two Hippocratic treatises explain what Rufus of Ephesus said much later in the first century AD on two types of melancholy:

It is makes a great difference, for the treatment, to find out how the illness began. One must know that there are two types of melancholy. Some people are naturally melancholic by virtue of their congenital temperament. By contrast, others acquire it later following an unhealthy diet. This second variety is

variety of dark bile. Also deriving from the adjective, we find the verb $\mu \varepsilon \lambda \alpha \gamma \chi 0 \lambda \hat{\alpha} \nu$, which is attested also in poetry (Aristophanes, Birds, line 14; Wealth, lines 12, 366, 903), with a wider meaning of 'being mad'. The use of the verb in the Hippocratic Corpus is not certain: in Diseases 1, ch. 30 (ed. Wittern 88,8), it is a varia lectio for $\mu \varepsilon \lambda \alpha \gamma \chi 0 \lambda \omega \dot{\delta} \eta$; and in Affections, ch. 36 , ed. Potter 58,11 , the passage is suppressed by Artelt and Potter (since it contradicts the treatise's bi-humoral theory of phlegm/bile). There is an abundant bibliography on the origins of melancholy and black bile, which includes W. Müri, "Melancholie und schwarze Galle," Museum Helveticum 10, 1953, pp. 21-38; J. Starobinski, Histoire des origines de la mélancolie des origines à 19oo, Basel, 196o; R. Klibansky, E. Panofsky and F. Saxl, 1964 (quoted in n. 1); E. Schöner, 1964 (quoted in n. 1); H. Flashar, 1966 (quoted in n. 1); J. Jouanna, ed. Nat. hom., 1975, pp. 48-50; R. Joly, "Sur une édition nouvelle de la Nature de l'homme," L'antiquité classique 38, 1969, pp. 151-154 and "Le Système cnidien des humours," in: L. Bourgey, J. Jouanna (eds.), La Collection hippocratique et son rôle dans l'histoire de la médecine (Colloque de Strasbourg, 1972), Leiden, Brill, 1975, pp. 107-127; J. Pigeaud, La maladie de l'âme, Paris, 1981, pp. 122-138; J.-M. Jacques, “La bile noir dans l'Antiquité grecque: médecine et littérature," Revue des Etudes Anciennes, 100, 1998, pp. 217-234; P. Dandrey, Anthologie de l'humeur noire, Paris, Gallimard, 2005. 
always accompanied by slowness and dullness of mind. Since it is following excessive combustion of yellow bile that these people are affected by delirium, they are more daring, quicker tempered than others, inclined to strike and commit dangerous acts, especially when this combustion of excessive bile takes place. Later, as time goes by, when the bile is extinguished, they become sombre, sad and timid. ${ }^{11}$

We saw that in this first important attestation of melancholy in Hippocrates, there is no indication of the symptoms of the disease. Can we find complementary information on this illness, particularly on its symptoms, in other Hippocratic treatises?

If we only look for the Greek word melancholie, the harvest seems poor. ${ }^{12}$ Melancholy appears once elsewhere in an enumeration of twelve nonfatal illnesses, save for complications, caused by black bile. ${ }^{13}$ This passage is certainly interesting for the prognosis of the illness and its possible outcomes, but it does not give any more information than Airs, Waters, Places on its symptoms. However, our investigation into melancholy in Hippocrates should not stop there, since melancholy can be designated not only by the noun melancholiê, but also by the adjective that derives from it, melancholikos. In this regard, we should bear in mind the semantic law of derivation according to which the derived adjective takes its meaning from the noun from which it derives. Since melancholie in the Hippocratic Corpus refers to a well-defined complaint_-regardless of whether it is due to bile that becomes black or to innate black bile-, the adjective melancholikos refers etymologically to something relating to this well-defined complaint. ${ }^{14}$ I will take as an example the most famous passage, that of Aphorisms (6.23):

11 Rufus of Ephesus, Frag. 70 (On Melancholy), ed. Daremberg-Ruelle, 1879, pp. 357,10$35^{8,6}$.

12 There are two other Hippocratic treatises (if we omit the apocryphal Letters, 9.358,12 L. and 9.398,23 L.) that mention the illness under this designation. One of them, Aphorisms, dating from the fourth century, is taken from the text of Airs, Waters, Places.

13 Diseases 1, ch. 3, ed. Wittern, 1974, p. 8,12-17 (= 6.144,12 L.): "The following diseases are not mortal, at least as long as there are no complications: kedmata, melancholy (melancholiê), gout, sciatica, tenesmus, quartan fever, tertian fever, strangury, ophthalmia, lepra, lichen and arthritis. But as a consequence of these diseases, the patients are maimed: they are paralysed in the hands and feet, powerless in speech and paraplegic, as a result of black bile ...."

${ }^{14}$ However, we should note that the adjective melancholikos, 'melancholic', sometimes has, from the Hippocratic Corpus onwards, a range of possible meanings that the corresponding noun does not have. In the neuter, it can mean black bile (see above, n. 1), or the temperament in which black bile dominates (see above, n. 2), or in masculine the temperament in which black bile dominates (cf. n. 2 above, the contrast between the two adjectives melancholikos and pikrocholos). The adjective can, in this case, refer to a healthy state rather than anything pathological. 
If the fear or despondency lasts for a long time, this is a melancholic state (melancholikon) ${ }^{15}$

By melancholikon we should understand etymologically that this state 'relates to melancholy', is characteristic of melancholy, and not in the wider sense 'caused by dark or black bile'. What is discussed here is not the cause of the illness, but its diagnosis. A prolonged fear or despondency allows us to identify a characteristic of the illness called melancholy.

Thus, the illness is characterised in Hippocrates firstly by a depressive kind of fear. It is also characterised by disturbances of the mind. We could even say that the disturbances of the mind in melancholy became standard features, since in his description of the state of a bed-ridden patient, the author of Epidemics 1-3 says "the state of the mind was melancholic (melancholika). ${ }^{{ }^{\prime \prime 6}}$ Doctors reading the patient's medical case complemented it with their own knowledge, which is no longer available to us. ${ }^{17}$ Explicit descriptions of the disturbances of the mind associated with melancholy are extremely rare in the Hippocratic Corpus. ${ }^{18}$

Besides fear or despondency, and a certain form of delirium, a third type of symptom characteristic of melancholy are troubles of speech or paralysis of a part of the body, as testified by a further Hippocratic aphorism:

If the tongue suddenly becomes powerless, or if a part of the body is struck by paralysis, this is a melancholic state (melancholikon). ${ }^{19}$

It is probably because of these latter symptoms that a relationship was established between melancholy and epilepsy. In Epidemics 6, the connection between the two illnesses is expressed thus:

Melancholics (melancholikoi) tend to become epileptic in the majority of cases, and epileptics are prone to becoming melancholic (melancholikoi).

15 Ed. Jones 4 (1931), 184,9f. (= 4.568,11f. L.). My interpretation is different from that by J. Pigeaud (Aristote, L'homme de génie et la mélancholie, Paris, Rivages, 1988, p. 58: "we should understand that such a state comes from the humour black bile or from the black character of the bile").

16 Hippocrates, Epidemics 3, 17 b, ed. Kuehlewein 1 (1894), 235,6 (= 3.112,11 f. L.).

17 Another Hippocratic testimonium points in the same direction. In Diseases 1, ch. 30 ed. Wittern (1974), 88, $7 \mathrm{f}$. (= 6.200,18f. L.), derangements of the mind during phrenitis are compared to those with melancholy: "concerning the derangement of the mind, those who are affected by phrenitis resemble above all those who are affected my melancholy."

18 The treatise Prorrhetic 1.123, ed. H. Polack (1954), 92,15f. (=5·552,5f. L.) considers short bouts of madness to be characteristic of melancholy.

19 Hippocrates, Aphorisms 7.40, 4.588,8f. L.; on paralysis of part of the body, cf. Aphorisms 6.56, ibid., 576,19f. These symptoms recall what is said in Diseases 1, ch. 3 (ed. Wittern $8,16 \mathrm{f}$. $=6.144,15 \mathrm{f}$. L.) about the consequences of a range of complaints, of which melancholy is one, due to black bile. 
Each of these two states arises according to the direction the disease takes; if it turns towards the body, people are epileptic; if it turns towards the mind, they are melancholic (melancholikoi). ${ }^{20}$

Thus, we have the three principal symptoms of melancholy, which sometimes affects the body, and more often the mind. For the Hippocratic doctors, this illness possessed a clear conceptual position between epilepsy and madness. It is no coincidence that these three illnesses form a triad in the enumeration of illnesses of autumn in the Aphorisms: epilepsy, madness and melancholy. ${ }^{21}$ However, the illness eludes any identification with a modern counterpart, which is the case for much Hippocratic nosology. ${ }^{22}$

In short, from this initial investigation of the Hippocratic Corpus, it appears that the three fundamental notions (the illness, the humour and the temperament) do not appear at the same time, nor are they necessarily associated with each other. The illness called melancholy pre-dates Hippocratic medicine. Black bile was born as a humour in its own right in Hippocratic medicine, which supposes that melancholy was attributed firstly to a pathogenic variety of bile. The melancholic temperament is rarely attested. There is no characterisation of it and it is not brought within the context of the theory of the four humours.

${ }^{20}$ Hippocrates, Epidemics 6, 8, 31, 5·354,19-356, 3 L. (= Manetti-Roselli 192, 10-194, 5). The Hippocratic Corpus, which is, as is well known, a collection of texts written by various authors, is not entirely coherent on this matter. In The Sacred Disease, ch. 5 (ed. Jouanna 12, $21 \mathrm{f}$.), it is said that epilepsy affects phlegmatics, and not the bilious.

21 Aphorisms 3.22, ed. Jones 4 (1931), 130, $6 \mathrm{f}$. (= 4.496,7 f. L.); cf. also springtime illnesses, ibid., 3, 20, ed. Jones 4 (1931), 128, 16 f. (= 4.494,16f. L.): madness, melancholy (or melancholy, madness), epilepsy.

22 I would like to conclude this discussion of melancholy in Hippocrates by warning against an approach that in my view is not sufficiently precise in that includes in the discussion on melancholy some texts where the terms melancholy, melancholic or black bile do not appear. This is the case, for example, in the illness called phrontis, 'worry', in Diseases 2.2, ch. 72 (ch. 61) (ed. Jouanna p. 211, 15f.), or those diseases that are called 'black illness', ch. 73 (ch. 62) and 74 (ch. 63) (ibid., p. 212,11f.). We must resist reinterpreting these illnesses with terms that are not there. In the oldest part of the treatise, Diseases 2, ch. $12 \mathrm{f}$. (which I have called Diseases 2 A or Diseases 22 ), black bile is not known as an independent humour, unlike the younger part of Diseases 2, chs. 1-12 (which I have called Diseases 2 B or Diseases 2 1). See J. Jouanna, Hippocrate. Pour une archéologie de l'école de Cnide, Paris, 1974, pp. 108-114. I believe that these illnesses belong to a stage prior to melancholy and offer a nosologic outline reflecting the prehistory of melancholy. At any rate there is no need to change the title from Phrontis into Phrenitis, as M. Gronewald proposes, "Bemerkungen zu Menander," Zeitschrift für Papyrologie und Epigraphik, 99, 1993, p. 24, even if J.M. Jacques (quoted in footnote 10), p. 233, finds this conjecture attractive. 
I will now consider how the starting points that we find in Hippocratic medicine in relation to melancholy and the melancholic temperament developed in post-Hippocratic medicine. Unlike other aspects of humoral theory, however, the study of melancholy and the melancholic temperament in Greek medicine cannot ignore a chapter that is found in the school of Aristotle and which is crucial for modern historians of melancholy and the melancholic temperament. This is the long discussion of the subject of melancholy in Problem 30.1. ${ }^{23}$ This Problem is well known, but I shall briefly summarise its content. It begins by raising the question why men who excel in philosophy, politics, poetry and the arts have a melancholic temperament, i.e. a temperament in which black bile dominates. The response dwells on a long and complex analogy with wine, whose different effects serve to explain the effects of black bile on the mind. This Aristotelian Problem has been called revolutionary. ${ }^{24}$ Yet what is the connection between this text and Greek medicine? Two questions arise here: is there a link between the Aristotelian concept and preceding medical, i.e. Hippocratic theory? Second: did the Aristotelian concept have an influence on post-Hippocratic Greek medicine? In other words, did Greek medicine become melancholic in the Aristotelian sense of the word?

As to the first question, careful comparison between Hippocratic medicine and the Aristotelian Problem suggests a predominately negative response. Even if we do not want to speak in terms of influence, the differences that exist between Hippocrates and Aristotle can clearly be seen.

First, we should remember that the Aristotelian Problem, whatever the identity of its author, was not the work of a doctor. He refers explicitly to doctors, which is proof that he is not one. Thus, the author is a nonspecialist, even if he has medical knowledge. This means that the approach to melancholy in the Aristotelian Problem is distinctly different, indeed the reverse, of that of the Hippocratic doctors. Hippocratic doctors are interested primarily in melancholy, whilst the Aristotelian Problem is interested primarily in the melancholic temperament. This notable difference in

23 This problem is traditionally attributed to Aristotle, although modern scholars are more inclined towards Theophrastus. See J. Pigeaud, Aristote, L'homme de génie et la mélancolie, Paris, Éditions Rivages, 1988, pp. 54-56. However, P.J. van der Eijk, Medicine and Philosophy in Classical Antiquity, Cambridge, 2005 (chapter 5, Aristotle on Melancholy = "Aristoteles über die Melancholie," Mnemosyne, 43, 1990, pp. 214-229 slightly adapted), pp. 139-168, sees no disagreement between the views of Aristotle and those of Problem 30.1 .

${ }^{24}$ See for example R. Klibansky, E. Panofsky and F. Saxl (quoted in footnote 1), p. 15 ("The notion of melancholy as revolutionised by the Peripatetics: Problem XXX,I"). 
perspective between Hippocrates and Aristotle partly explains the difficulties posed by the question of the links of the Aristotelian Problem with Hippocratic medicine. I will pursue the comparison by taking the three fundamental elements: illness, temperament and humour.

Concerning the illness, the Aristotelian Problem, unlike Hippocrates, never uses the noun melancholiê. If we wanted to be provocative, we could say that melancholy virtually does not exist as such in the Aristotelian Problem. The adjective melancholikos is certainly frequent, but its meaning has become wider, even in the domain of nosology. Whilst in Hippocrates it meant, in accordance with its etymological sense, 'relating to melancholy', in the Aristotelian tradition it has adopted the widened meaning of 'relating to black bile'. The reason is that the author of the Problem does not refer to the particular complaint that the Hippocratic doctors called melancholy, but rather more generally to all illnesses caused by black bile. ${ }^{25}$ From Hippocratic melancholy, it has progressed to melancholic complaints in general. The consequence is that the nosologic model established by specialists disappears, to privilege only the connection with black bile. ${ }^{26}$

The attention that I pay here to the nosologic vocabulary and to the difference we find between the use by specialists (doctors) and non-specialists (philosophers and others) is not simply excessive nit-picking by a philologist seized by melancholy, but rather a necessary step to rediscover secure

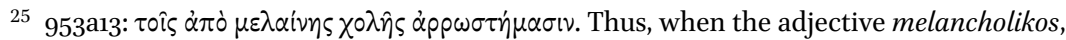
in a nosologic context, is used in the neuter singular it refers to an illness caused by black bile (954a28: vó $\eta \eta \mu \dot{\alpha} \tau \iota \mu \varepsilon \lambda \alpha \gamma \chi 0 \lambda$ เxóv) and, in the neuter plural, the illnesses caused by black bile

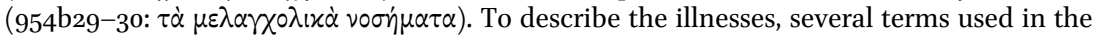
Problem are synonymous ( $\dot{\alpha} p \rho \omega \dot{\omega} \sigma \tau \eta \mu \alpha, v o \sigma \dot{\eta} \mu \alpha \tau \alpha$; also $\pi \dot{\alpha} \theta \eta)$. There is no difference between these terms, contra P. Dandrey (quoted in footnote 10), p. 39, footnote 1 (in fine). His crossreference to Pigeaud, footnote 17, p. 113, does not work because Pigeaud does not establish a difference between the meanings of these two terms.

${ }^{26}$ The only passage of the Problem that seems to me to mean melancholy in the Hippocratic sense of the term is found in the comparison between the effects of black bile and wine. Concerning the effect of wine drunk in too much quantity, we read (Aristotle, Problem 30.1, 953b6): "Drunk in too great a quantity, wine relaxes and makes the individual silly, like those who are epileptic from childhood or those who are strongly affected $\tau 0 i \varsigma \mu \varepsilon \lambda \alpha \gamma \times 0 \lambda$ ixoî, i.e. by melancholy." The neuter plural ta melancholika cannot mean here illnesses caused by black bile in general, for the simple reason that in the Problem, epilepsy was already included in diseases caused by black bile. Thus, putting it in the same sentence here supposes that $t a$ melancholika has a more restricted meaning and means melancholy in the Hippocratic sense of the term. This interpretation is all the more likely considering the connection established between epilepsy and melancholy in several other Hippocratic treatises (Epidemics 6, Aphorisms). Thus, we may detect contact with Hippocratic medicine in this passage. However, we are certainly far from finding in the Problem the precision of the nosologic outline that we found in Hippocratic medicine. 
traces of the complicated history of melancholy. I will not pursue this avenue of research, which some may find dry and others exciting, much further, but I cannot resist tracing the development of this nosologic vocabulary in an author who read Aristotle's Problem in the second century AD, i.e. Plutarch.

The Aristotelian Problem chose Lysander as an example of an eminent politician whose temperament was melancholic. Plutarch, in his Life of Lysander, refers to this as follows:

Aristotle, showing that great natures are melancholic (melancholikas), such as Socrates, Plato, and Heracles, tells us that Lysander, not at first, but in old age, suffered from melancholy (melancholia). ${ }^{27}$

Plutarch's reading introduces a new simplification into the medical domain. Aristotle's Problem said that Lysander had some ulcers towards the end of his life, and that these ulcers were caused by black bile. Plutarch instead reintroduces the noun melancholia, which was absent from the Problem. Yet in doing so, Plutarch does not return to the melancholy of the Hippocratic doctors; this is a different melancholy, which has expanded to include all illness caused by black bile. ${ }^{28}$ In non-specialist usage, melancholy no longer refers to a particular illness of black bile, but to the illness of black bile more generally, encompassing all illnesses caused by black bile. We can explain this semantic expansion of the noun melancholia by the intermediary of the Aristotelian Problem, which departed from the distinctions of Hippocratic nosology by widening the meaning of the adjective melancholikos to include illnesses caused by black bile in general.

Let us continue with the comparison between Hippocrates and Aristotle. The difference is larger still concerning the melancholic temperament, in which black bile dominates. The Problem clearly takes a new direction which is completely different from Hippocrates. For example, the Problem introduces a psychological dimension to the melancholic temperament and justifies this by a long comparison with wine. All this is not found in Hippocrates. The Problem also takes as its point of departure a value judgement, which it presents as a given, i.e. the excellence of the melancholic temperament, which is the source of all the elite men of philosophy, politics, poetry and the arts. That this notion is not of a medical origin is reinforced by the

27 Plutarch, Life of Lysander, ch. 2, $5\left(175^{\mathrm{b}-\mathrm{c})}\right.$.

28 Plutarch returns to Lysander's melancholy at the end of this discussion, where he connects it with his difficult character (ch. 28, 1: "Lysander was a difficult character due to melancholy, which became more intense in old age ...”). It is this psychological aspect of melancholy that interests Plutarch, although it does not appear in his model. 
subsequent discussion because, by reserving this excellence for those who are melancholic not by illness but by nature, the author of the Problem goes beyond the doctor's domain. The very basis of what makes the Aristotelian Problem famous does not seem to be of medical, and certainly not of Hippocratic, origin.

Even the concept of black bile in the Aristotelian Problem is different to that of Hippocratic medicine. Of course, there is a possible connection, to the extent that black bile is an innate humour in both the Problem and in Nature of Man. However, the author of the Aristotelian Problem does not seem to have known this Hippocratic treatise: there is no trace of a theory of four humours, and, above all, the Aristotelian Problem takes as its basis a concept of black bile that is incompatible with that of Nature of Man. This is a fundamental point: while in Nature of Man, black bile is a cold and dry humour, corresponding with autumn, the cold and dry season, the Aristotelian Problem presents black bile, a natural humour, in a very different way:

This melancholic humour is present in the body as a mixture from the beginning and by nature. Indeed, it is a mixture of hot and cold. Its nature is constituted by these two principles. It is because of this that black bile can be extremely hot or extremely cold. ${ }^{29}$

Thus, a single humour can have totally opposite effects and provoke in those who are melancholics through illness two afflictions with contrasting symptoms: if black bile is cold, it provokes despondency and fear (which are the symptoms of Hippocratic melancholy; on this precise point, there is agreement); but if black bile is heated, it provokes the reverse behaviour, being joyous and singing-such symptoms are not Hippocratic..$^{30}$ What is more peculiar is that melancholics are also divided by nature into two radically opposed categories according to the temperature of the black bile at their birth:

Those in whom black bile pre-exists in excess and is cold are slow and silly; those in whom black bile pre-exists in excess and hot are impassioned, talented, inclined towards love and easily led to anger and desire, some being rather talkative. Quite often, since this heat is close to the seat of the intellect, they are taken by diseases such as mania and enthusiasm; this explains the Sibyls, the soothsayers and all those inspired, if they are like this, not by disease, but by natural temperament. ${ }^{31}$

\footnotetext{
29 Problem 30.1 (954a12).

30 Problem 30.1 (954a21-26).

31 Problem 30.1 (954a30-38).
} 
A single humour that can be either colder or warmer at the time of birth is contrary to Hippocratic thinking, and particularly to that of the author of Nature of Man. In medical thought, one and the same innate humour cannot be defined by the mixture of two opposed elemental qualities: it is not a mixture of cold and hot, but it is, by nature, either hot or cold. ${ }^{32}$ The same goes for dryness or wetness. What the Aristotelian Problem explains by the opposite effect of the same humour was, in Hippocratic medicine, the work of two naturally opposed humours: bile and phlegm. In fact, the Hippocratic treatise The Sacred Disease distinguishes between two types of madness: the madness of excited people, caused by bile, a warm humour, and the opposite madness of calm people, caused by phlegm, a cold humour. ${ }^{33}$ The Aristotelian tradition is outside the Hippocratic medical tradition, to the extent that it attributes two opposing characteristics to a single humour, black bile.

In short, Hippocratic medicine cannot be the principal source of the Aristotelian Problem, neither for the joyous madness of melancholic affections, nor for the melancholic temperament, nor for its concept of black bile. Aristotelian melancholy is fundamentally not Hippocratic. ${ }^{34}$

What about medicine after Hippocrates? Does it follow the Hippocratic medical tradition? Was it influenced, in addition, by the Aristotelian tradition? I will consider this double question in two ways; firstly, from the complaint called melancholy, and then from the temperament in which black bile dominates.

A well-known problem of post-Hippocratic Greek medicine is posed by the great lacuna caused by the loss of the writings of the medical authors in the three centuries after him. Melancholy as an illness did not reappear

\footnotetext{
32 The position of the Problem on the definition of black bile according to the elemental qualities is very delicate to understand. It is naturally a combination of hot and cold, which gives it the possibility of being very hot and very cold, but it is said at the same time to be

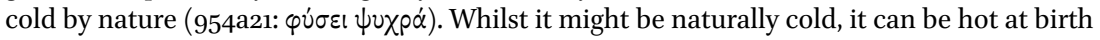
(954a32).

${ }^{33}$ Hippocrates, The Sacred Disease, ch. 15 , ed. Jouanna 27, 5-11. We note the contrast in the seat of intellect: the head in the Hippocratic treatise, the heart in the Aristotelian Problem.

${ }^{34}$ Instead, we should rather consider whether Diocles of Carystus may have had more influence than Hippocrates on the Aristotelian conception (although Diocles' date is uncertain). The Problem mentions doctors with regard to flatulent or hypochondriac illnesses, which are caused by black bile (953b24-25). This cannot allude to Hippocrates (where they are not mentioned), but very probably to Diocles. Indeed, for the labelling of flatulent dis-

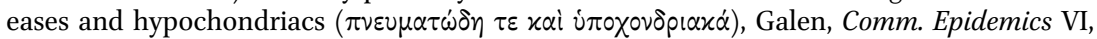
3, 12 (ed. Wenkebach 138, 19 f. = 17b29,10 K.) looks firstly to Diocles, and to Pleistonicus. By insisting on the flatulent character of melancholic illnesses, the Problem attaches itself to the medical tradition of Diocles.
} 
in the direct tradition until Aretaeus of Cappadocia, a doctor from the first century $\mathrm{AD}$, and Galen, a doctor from the second century AD. Between these two periods, we possess only indirect information. We know that Diocles of Carystus, in the fourth century, had discussed a form of melancholy, different from that of Hippocrates, affecting the stomach. Galen quotes fairly long extracts. ${ }^{35}$ However, the lacuna in the history of melancholy in Greek medicine from the Hellenistic period is not only accidental. It occurred because the humoral view of man was replaced in this period by a solidist view. Thus, Galen reproaches one of the two most important doctors of this period, Erasistratus, for not having written anything about melancholy and for failing to account for the humoral faculty. ${ }^{36}$

Despite this large gap in the history of Greek medicine, due to both lack of evidence and an intermission of humoral pathology, the Hippocratic conception of melancholy remains strongly present in the medical tradition of the Roman period. This is explicitly recognised by Galen. When he discusses melancholy in his On Affected Places 3, ch. 10, he comes to quote and comment on two passages of Hippocrates: the passage from Epidemics 6 on the connections between epilepsy and melancholy, ${ }^{37}$ and Aphorism 6.23 on the symptoms of melancholy. Having highlighted the different kinds of fear that can afflict melancholics by means of very clear examples, none of which are found in the Hippocratic Corpus, ${ }^{38}$ Galen concludes by stating:

Hippocrates seems to have been right to reduce under two headings the

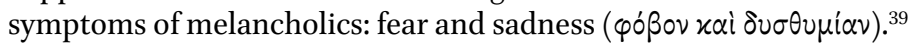

Thus, Galen's nosologic model remains Hippocratic. ${ }^{40}$ The melancholic illness remains what it was in Hippocrates, a well-determined illness, included

35 Galen, De locis affectis 3, ch. 10 (= 8.186,1 f. K.).

36 Galen, De locis affectis 3, ch. 10 (= 8.191,12-14 K.).

37 Ibid., 180, 6-8.

38 Here is Galen's discussion on these cases: "Melancholics are prone to fears; but the fantastic images do not always appear to them in the same form. Thus, one imagines he is made of shells and so is scared of being crushed. Another, seeing a cockerel sing who flaps his wings before singing, imitates the voice of the animals and beats his side with his arms. Another fears that Atlas, tired from the weight of the earth he supports, cannot support his burden, and in this way, fears from time to time that we are all going to perish. And innumerable other such ideas go through their mind. There is a difference between melancholics. All are prone to fear, to sadness, they blame life and hate men, but they do not all wish to die. By contrast, in some the main characteristic of melancholy is fear of death. Others seem odd; they fear death and at the same time desire it." (190)

${ }^{39}$ Galen, De locis affectis 3 , ch. 10 (= 8.188,6f. K. and 8.190,17-19 K.).

40 Another quotation and use of Aphorism 6.23 in De symptomatum causis 2, ch. 7, 7.202,18-203, 3 K. (quotation 203, 3-4). 
amongst the complaints caused by black bile. ${ }^{41}$ This has an important consequence for our question. The derangement of the mind caused by melancholy in Hippocrates and Galen cannot align with the Aristotelian concept of two opposed, ecstatic and depressive forms of melancholic afflictions. A joyous madness caused by melancholy finds no place in Galen. Scholars have said that Problem 30.1 on melancholy was the most famous of the Aristotelian Problems. However, the problem, if I may say so, is at what time and in what context it was famous. Galen quotes once in his work an Aristotelian Problem on melancholy, but it is not this one. It is the Problem on the propensity of melancholics to make love..$^{42}$ It is important to keep in mind Galen's impermeability to what we consider the central Problem of Aristotle, for there is no doubt that it was Galen who determined the direction in which later Greek medicine continued.

One may object that Galen is a textbook case and that Hippocrates' influence does not manifest itself so clearly in Galen's predecessors. Yet the only predecessor whose description of melancholy has been preserved in its entirety is Aretaeus of Cappadocia, whose nosologic description stands in direct connection with Hippocrates. It is no coincidence that Aretaeus, in his account of chronic illnesses, successively discusses epilepsy, melancholy and madness. It is the famous Hippocratic triad that we find in the enumeration of autumn (and spring) illnesses given in the Aphorisms. ${ }^{43}$ Furthermore, melancholy is defined in Aretaeus as it was in Hippocrates, as despondency (athumiê), with the addition that the despondency is due to an obsession and that the illness is without fever. ${ }^{44}$

Should we nevertheless agree that the Aristotelian Problem influenced the other face of Hippocrates known to the Renaissance, i.e. that of the

\footnotetext{
${ }^{41}$ A passage from his Commentary on Hippocrates' Aphorisms is in this respect very characteristic. Galen enumerates the afflictions caused by black bile ( 17 B 659,9-66o,3 K.): "In fact, due to black bile, the colour of the whole body turns black; and the exanthems are black due to the colour of black bile. All the complaints that are caused by an abundance of black bile clearly show the strong presence of the humour, such as elephas and carcinoma. Quartan fever also comes from the melancholic humour. The inflammation of the spleen, dark varicose veins, are complaints originating from this same humour, also called melancholy $(\dot{\eta}$ $\mu \varepsilon \lambda \alpha \gamma \chi 0 \lambda i \alpha x \alpha \lambda \circ u \mu \varepsilon \dot{v} \eta)$, and all perturbation of intelligence which is quick-tempered, bold,

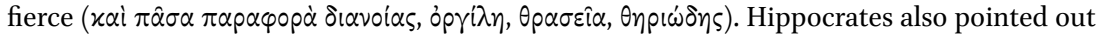
the abundant presence of the humour in women, on the basis of menstruation, and he described its signs in the first book of Diseases of Women."

${ }^{42}$ Commentary on Hippocrates' Epidemics VI, 3.12 ed. Wenkebach 139,2-5 = 17b29,13-17 K. = Problem 4.30 (880a30-33): "Why are melancholics prone to making love?"

${ }^{43}$ See supra, p. 236.

44 Aretaeus of Cappadocia, 3, ch. 5, ed. Hude ${ }^{2}$, 39-40.
} 
Letters, which were written later than the medical treatises? In the famous story of Hippocrates and Democritus, melancholy is mentioned during the discussion of Democritus' madness, for which the Abderans asked for Hippocrates' help. Some modern scholars have wanted to connect this reference to melancholy with the Aristotelian Problem, where philosophical geniuses have a melancholic temperament. ${ }^{45}$ However, let us re-read the letter where melancholy is discussed. It is the Letter of Hippocrates to Philopoemen (letter 12), where Hippocrates thanks Philopoemen for his hospitality at Abdera, were he went at the invitation of the Abderans to cure Democritus. The actual discussion of the symptoms of melancholy compared to the behaviour of the wise man is found in the following passage:

The following symptoms often happen to melancholics (melancholôsi): they are sometimes taciturn and solitary; and they love deserted places; they avoid company, thinking that when they see people close to them they see strangers. In the same way people who are passionate about acquiring knowledge abandon all other preoccupations in order to obtain knowledge. ${ }^{46}$

This description of melancholy is interesting from a medical point of view since it explicitly describes symptoms that remained implicit in the medical writings of Hippocrates, and which correspond to those found in doctors that came after him: Aretaeus of Cappadocia, Rufus of Ephesus or Galen. For example, fear or hatred of men is a symptom pointed out by all these medical writers. ${ }^{47}$ Now it is certainly true that we find the symptom of isolation already in the Aristotelian Problem; thus, Bellerophon, who "sought deserted places, ${ }^{\prime \prime 8}$ is taken as an example of a melancholic temperament. However, there is an essential difference between the melancholic model of Aristotle and the Hippocrates of the Letters. Whilst in the Aristotelian tradition, the melancholic temperament explains the excellence of any philosopher, the Hippocrates of the Letters, whilst highlighting the comparison between the symptoms of melancholy and the behaviour of the wise man,

${ }^{45}$ See for example P. Dandrey (quoted in footnote 10), p. 67 (regarding the Hippocratic Letters on the madness of Democritus): "There are two threads to this story: one medical, clearly attached to the pathological doctrine of the melancholic temperament and to the analyses of Problem 30.1; the other moral ... which discusses ... the topic of the inaccessible and misunderstood wise man." See also J. Pigeaud (quoted in footnote 10), p. $457 \mathrm{f}$.

${ }^{46} 9 \cdot 330,13-16 \mathrm{~L}$.

47 For Aretaeus of Cappadocia, see 3, ch. 5, ed. Hude², 40,2: "They flee into solitude for hatred of men"; for Rufus of Ephesus, see frag. 70 (On Melancholy), ed. Daremberg-Ruelle, 1879, p. 354, 11-12: "One fears his family and friends and the other all men"; for Galen, see $D e$ locis affectis 3 , ch. 10, 8.190,12 f. K.: "to hate men."

48 Aristotle, Problem 30.1 (953a22). 
makes this comparison only in order subsequently to contrast a melancholic's madness with the wise man's ataraxia. Thus, the wise man here does not have a melancholic temperament at all and the position of Hippocrates in the Letters is different from that of the Aristotelian Problem. ${ }^{49}$

Despite this, do there exist possible influences of the Aristotelian Problem on the nosology of melancholy in Greek medicine? What became of the Aristotelian Problem's second form of melancholic complaints in Greek medicine, i.e. joyous delirium? The problem has already been posed concerning a passage by Aretaeus, which I just mentioned (see n. 44 above), where the manuscripts present a clear error of thumêdiê, 'joy', instead of its opposite athumiê, 'despondency'. Those who do not correct the text arrive at an untenable contradiction. When Aretaeus defines melancholy as despondency (athumiê), how can we translate, with Coray, three lines later that melancholics are "continually in bad humour or continually happy"? Despite my admiration for Coray, this translation is untenable. ${ }^{50}$ According to Aretaeus, man's delirium brought on by melancholy is uniquely depressive, and if signs of joy appear from time to time, it is a sign that the person's melancholy has changed into mania. ${ }^{51}$ In fact, according to Aretaeus, melancholy is often the start (or a part) of mania.

${ }^{49}$ For a comparable position, see Th. Rütten, Demokrit: lachender Philosoph und sanguinischer Melancholiker. Eine pseudohippokratische Geschichte (Mnemosyne. Suppl. 118), Leiden, Brill, 1992, p. 125f. Moreover, apart from the description of melancholy in the Letter to Philopoemen, the vocabulary of melancholy is rare in the rest of the Letters, and it plays an insignificant role, apart from the diagnosis of melancholy envisaged provisionally by Hippocrates but which will turn out to be false: $\mu \varepsilon \lambda \alpha \gamma \chi \chi \lambda \hat{\alpha} \nu$ (Letter to Damagetus I, 9.338,17 L.: false diagnosis regarding Democritus); $\mu \varepsilon \lambda \alpha \gamma \times$ xo $\lambda$ in: Letter to Damagetus II, 9.358,12 L. (in an enumeration of the symptoms) and Letter to the King Demetrius, 9.398,23 L. (aphorism on melancholy: spasms occurring in melancholics stop the melancholies); and $\mu \varepsilon \lambda \alpha \gamma \times 0 \lambda$ ixós, Letter from Hippocrates to Philopoemen, 9·330,14 L. (see above) and Letter to King Demetrius $9 \cdot 398,23 \mathrm{~L}$. (see above). The rarity of the term in the Letters contrasts with the importance that modern scholars accord to the Letters in the history of melancholy.

50 Coray's translation of this chapter on melancholy can be found, for those who cannot consult the whole of Coray's translation in the Pragmateiai of the Academy of Athens, vol.13, 3, Athens, $195^{\circ}$ (published by Aristote P. Kousis after the manuscript 191 in the Library of Chios) in P. Dandrey, Anthologie de l'humeur noire, Paris, 2005, p. 135. See also the position of Laennec, who had translated it with 'découragement' ('despondency') and replaced it after with 'joyousness' in R.T.H. Laennec, Arétée de Cappadoce. Des causes et des signes des maladies aiguës et chroniques, ed. M. Grmek, Droz, 2000, p. 73. Laennec had already made the connection with the symptom of joy in Paul of Aegina when he translated it with 'despondency'. We do not know the reasons for his correction, which goes back to the manuscripts.

51 Aretaeus of Cappadocia, 3, ch. 5, ed. Hude 2 , 40,3-5. 
On the other hand, there is a doctor much later than Aretaeus for whom joy is a symptom of melancholy: Paul of Aegina, a medical writer from the seventh century AD. His definition of melancholy appears similar to that of Aretaeus, apart from a small, but important, detail. Whilst Aretaeus defined it as despondency (athumiê) without fever, Paul of Aegina defined it as madness (paraphrosunê) without fever. This is an important difference, because it permits the introduction of joy into the account of the symptoms. Of course, Paul of Aegina begins with the traditional symptoms in postHippocratic Greek medicine (fear and despondency), but he adds cases where certain people laugh. This is incontestably an innovation compared to the Hippocratic tradition. ${ }^{52}$ Should we see here an indirect influence of the Aristotelian Problem? We should add in this respect that Paul of Aegina mentions that some melancholics believe themselves to be possessed by a divinity or to be able to predict the future,$^{53}$ a symptom we saw mentioned in the Aristotelian Problem. ${ }^{54}$ However, the doctor focuses on the symptoms of the illness, whilst in the Aristotelian tradition the real capacity to predict the future in a state of enthusiasm is accorded to a select group amongst those who have a melancholic temperament. Thus, an influence of the philosophical tradition on medicine is possible but, if it exists, it is limited.

We must add a parallel little known by commentators on Aristotle's Problem. In the pseudo-Galenic treatise Introduction or Doctor, the author, having stated that yellow bile is the cause of madness, says that black bile is the cause of melancholy:

The cause of melancholy is black bile, a humour that is colder and darker. This is why such patients are troubled and despondent, distrustful of everything, misanthropic and desirous of solitude, such is said of Bellerophon (Iliad VI, 201-202): He wandered alone on the Aleiean plain, eating his heart out and fleeing from men..$^{55}$

${ }^{52}$ In Alexander of Tralles (sixth century), too, we find a type of melancholy where the patients laugh for no reason. Alexander insists on the diverse manifestations of this illness, which are due to the fact that it is not caused by one single humour. Thus, this aetiology of melancholy is not analogous to that of the Aristotelian Problem, which explains all the symptoms, even the most contrasting, by one single humour: black bile.

53 This symptom was mentioned by Rufus of Ephesus according to Rhazes (Frag. 127 Daremberg-Ruelle, p. 456,1f.) "Et contingit quod quidam istorum narrant et somniant praeter solitum, et pronosticantur futura, et eveniunt quae ipsi praedicunt."

${ }^{54}$ Problem 30.1, 954a34-37 (quoted supra, p. 240). It even uses two comparable terms

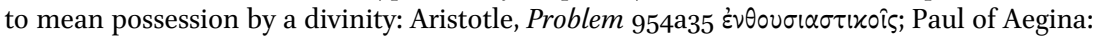

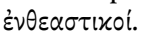

$5514,740-741 \mathrm{~K}$. 
By taking Bellerophon as an example of a melancholic hero and by quoting two verses from Homer, pseudo-Galen attaches himself to the Aristotelian Problem. Indeed, at the start of the Problem, Bellerophon is mentioned amongst the mythological examples of great melancholics, along with Heracles and Ajax, and it also quotes the verses from Homer. This similarity is probably not due to chance, and is most likely to be explained by assuming that pseudo-Galen refers to Aristotle's Problem without quoting it, unless the similarity is explained by a common model.

Thus, it is possible that there are sporadic souvenirs of the Aristotelian Problem, above all in a late period. However, the descriptions of Greek doctors in the Roman period remain in a continuous line with the analyses of Hippocrates and his nosologic model. Of course, their descriptions are more explicit in detailing symptoms and more complex in distinguishing three types of melancholy, which had been established at least from Galen, ${ }^{56}$ not to mention their integration of innovations from the Hellenistic period, notably the symptom given by Aretaeus of the melancholic's pulse. ${ }^{57}$ However, the depressive character of the illness remains fundamental. Greek medicine is not melancholic in the Aristotelian sense of the term.

Let us now turn to the history of the melancholic temperament in Greek medicine. Theoretically, conditions are more favourable to a diffusion of the analyses of the Aristotelian Problem; Hippocratic medicine offered practically nothing compared to the analyses of the Problem, whose originality lies especially in the development of the psychological aspects of the melancholic temperament. However, it is again a Hippocratic starting point that is at the root of a typology of temperaments in later medicine, and not the Aristotelian tradition.

We saw that the theory of the four humours in the Nature of Man had not yet given rise to a theory of four temperaments. However, Galen contributes to the exceptional fate of the four humours at the end of Antiquity and the Middle Ages, by attributing to Hippocrates what was actually the work of his student, Polybus, and considering the theory of the four humours to be the

56 Galen, De locis affectis 3.10. The third type is hypochondria or flatulence, on which Galen quotes rather long passages from Diocles of Carystus. Galen is obliged to refer to Diocles because this third type does not belong to the Hippocratic tradition. Cf. also the definition given by pseudo-Galen, Medical Definitions, 19.416,9-13 K.: "Melancholy is a complaint that affects the mind with emphatic despondency and with turning away from one's most loved people, unaccompanied by fever; in some, there is so much black bile that it affects the stomach, so that they vomit it and, in this way, their mind is hurt." The three types of melancholy are clearly found in Paul of Aegina.

57 Aretaeus of Cappadocia 3, ch. 5, ed. Hude ${ }^{2}, 41,3$ f. 
fundamental teaching of the father of medicine. However, the theory of the four temperaments which results from this was not known in its definitive form until a period after Galen. ${ }^{58}$ This last stage is represented by several Greek or Latin texts from Late Antiquity.

Some of these have been highlighted and compared in the now classic study on melancholy by Raymond Klibansky, Erwin Panofsky and Fritz Saxl, Saturn and Melancholy. In this work, two Greek texts (pseudo-Galen On the Humours, and an anonymous On the Constitution of the Universe and of Man) and two Latin texts (pseudo-Soranus, Isagoge Saluberrima and Vindician, Letter to Pentadius) are presented in columns. The texts are compared and briefly commented on ${ }^{59}$ Following the publication of an unedited Armenian text by Jean-Pierre Mahé on the four humours and the four temperaments, I was able to undertake a study of these texts and add others to it, both edited and unedited. ${ }^{60}$ Without being able to enter here into the detail of this investigation, I would like to point out briefly what this study adds by way of novelty compared to Klibansky, firstly on the date of the appearance of the theory of the four temperaments, and then on the melancholic temperament.

We must firstly make an important correction to the date of the appearance of the theory of the four temperaments. Klibansky believes that the pseudo-Soranic Isagoge Saluberrima can be dated to the third century AD, earlier than Vindician's Letter. Vindician, we should remind ourselves, is a doctor thought to date from the fourth century $\mathrm{AD}$, from the province of Africa, known to Augustine. However, when we compare the section on the humours and the temperaments in pseudo-Soranus and Vindician, pseudo-Soranus seems to represent a more developed version of a part of the manuscript tradition of Vindician's Letter. Thus, pseudo-Soranus can

58 Galen undoubtedly constitutes an important stage in the elaboration of the theory of the four humours and of the four temperaments. However, he does not present an elaborated theory of the four temperaments. See for example E. Schöner, Das Viererschema in der antiken Humoralpathologie in Sudhoffs Archiv, Beiheft 4, Wiesbaden, 1964, pp. 86-93; J. Jouanna and J.-P. Mahé, "Une Anthologie médicale arménienne et ses parallèles grecs," CRAI, 2004, pp. 549-598 (pp. 564-566); J. Jouanna, "La Postérité du traité hippocratique de la Nature de l'homme: la théorie des quatre humeurs," in Ärzte und ihre Interpreten. Medizinische Fachtexte der Antike als Forschungsgegenstand der Klassischen Philologie, Fachkonferenz zu Ehren von Herrn Dr. sc. Diethard Nickel, (Berlin, 14-15 May 2004), Berlin, 2006, pp. 123-147 (pp. 125-128); see chapter 16 in the present volume.

59 R. Klibansky, E. Panofsky, F. Saxl (quoted above in footnote 1), pp. 62-63.

${ }^{60}$ J. Jouanna and J.-P. Mahé, "Une Anthologie médicale arménienne et ses parallèles grecs," quoted in footnote $5^{8 .}$ 
only post-date Vindician's Letter. ${ }^{61}$ Moreover, we still do not know if Vindician's Letter is authentic or if, as I believe, it is a fabrication elaborated from a Greek discussion of the four humours and the four temperaments. ${ }^{62}$ The only date that is currently certain as a terminus ante quem for the appearance of the theory of the four temperaments is provided by Bede, who presents the theory of the four temperaments in his De temporum ratione (ch. 35 De quatuor temporibus, elementis, humoribus), datable with certainty to $725 \mathrm{AD}$. The theory necessarily pre-dates that date, and I have hypothesised that it might date to the second renaissance of Greek medicine in Alexandria in the sixth century, possibly through the intermediary of the Latin translation through Ravenna. ${ }^{63}$ In any case, we can no longer rely on the dating of the Isagoge Saluberrima to date the appearance of the theory of the four temperaments to the third century AD.

To finish our discussion of the melancholic temperament within the theory of the four temperaments, we come now to some new documents not included by Klibansky. ${ }^{64}$ Firstly, we should recall the context in which the portrait of the melancholic is found. The melancholic temperament comes in third position in an order that is generally fixed:1. sanguine temperament;

61 For a criticism of the early date of pseudo-Soranus, see K.-D. Fischer, "The Isagoge of Pseudo-Soranus. An Analysis of the Contents of a Medieval Introduction to the Art of Medicine," Medizinhistorisches Journal, 35, 2000, pp. 3-30 (p. 20, footnote 45). According to Fischer, the treatise dates to the early Carolingian period. On the connections between Vindician's Letter and Pseudo-Soranus, see J. Jouanna, "La Théorie des quatre humeurs et des quatre tempéraments dans la tradition latine (Vindicien, Pseudo-Soranus) et une source grecque retrouvée," Revue des Etudes Grecques, 118, 2005, pp. 138-167.

62 See J. Jouanna (2005), quoted in footnote 61. I also mention here a supplementary witness. The elaborated theory of the four humours and the four temperaments in the letter attributed to Vindician does not seem to have been known to Isidore of Seville (56o-636), since in his work on On Numbers, ch. 23, we read, with regard to the fourth number, that the world is made up of four elements (fire, air, water and earth), the year of four seasons and man of four elemental qualities (hot, cold, wet, dry); see the edition by Jean-Yves Guillaumin, Isidorus Hispalensis, Liber Numerorum, Paris, Belles-Lettres, 2005, p. 30.

63 See J. Jouanna and J.-P. Mahé (2004), quoted in footnote 58, p. 582 f.; J. Jouanna (2005, quoted in footnote 61, pp. 166-167, with footnote 44 bearing a new element).

64 I add two Greek texts that have already been edited and two Greek texts that remain unedited, not to mention the translations into Hebrew or Armenian. On the translation into Armenian, see J. Jouanna and J.-P. Mahé, quoted in footnote 58 . Here is the passage on the melancholic temperament (p. 584): "He who has too much black bile, his face is black and puffy with fat. He is very quick tempered and loves solitude and silence. He is very troubled and holds grudges and has fits of fear." On the translation into Hebrew, see E. Peyser, Eine hebraïsche medizinische Handscrift. Beitrag zur Komplexionenlehre, Diss. Basel, 1944, pp. 3133. Here is the passage on the melancholic temperament: "The masters of medicine said that the bodies of people with black bile are cold and dry like the earth, and that their heart and thoughts are in constant fear of things which there is no need to fear." 
2. bilious temperament; 3. melancholic temperament; 4. phlegmatic temperament. This order is probably explained by the successive predominance of the humours according to age: blood in infancy, yellow bile in youth, black bile in maturity and phlegm in old age. Each temperament is the subject of a brief discussion of its physical or moral characteristics. I would add, to finish with this general outline, a remark on vocabulary. The temperaments are not designated by an adjective corresponding to the humour, but by a periphrasis. Thus, the Greek does not say "melancholic people" but "those in whom black bile is found," and so we do not find the terms melancholia or melancholikos. Only the word for black bile (melaina cholê) is used. Nevertheless, for reasons of convenience I will speak of the melancholic temperament.

Despite a comparable scheme of exposition, the content of the discussions can vary. From the diversity of descriptions, some groups appear to correspond to different portraits of melancholics. To take an example, I will focus here on three principal groups. ${ }^{65}$

The first group comprises three Greek texts. Of these three texts, Klibansky knew only one: the anonymous On the Constitution of the Universe and of Man, which is the best known Greek text on the theory of the four temperaments. To this we must add two letters, one attributed to Hippocrates (but which does not form part of the corpus of Letters of Hippocrates known to the Renaissance), the Letter from Hippocrates to Ptolemy (the long version), and the other a letter attributed to John of Damascus, called Quid est Homo ${ }^{96}$ Here is the discussion of the melancholic temperament in these three texts:

A. Of the Constitution of the Universe and of Man (ed. Ideler, 2.304):

Those who are constituted of black bile are indolent, pusillanimous and sickly (philasthenoi); as for their bodies, they have black eyes and black hair. ${ }^{67}$

B. Letter from Hippocrates to Ptolemy (long version, ed. Ermerins, Anecdota Medica graeca, Lugduni Batavorum, 1840, p. 281):

${ }^{65}$ In J. Jouanna and J.-P. Mahé (2004), quoted in footnote 58, p. 568 f. I have distinguished these three groups of Greek texts presenting the theory of the four humours.

${ }^{66}$ On this letter, see J. Jouanna, "Le Pseudo-Jean Damascène, Quid est homo?," in V. Boudon-Millot and B. Pouderon (ed.), Les Pères de l'Église face à la science médicale de leur temps, Paris, Beauchesne, 2005, pp. 1-27.

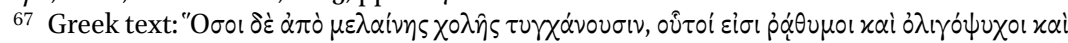

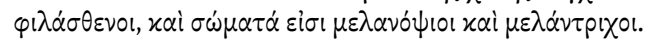


$\langle$ Those who are constituted of black bile $\rangle$ are indolent, pusillanimous, cowardly, sickly (philasthenoi). ${ }^{68}$

\section{John of Damascus, Quid est homo? (ed. Migne $P G$ 95, 244):}

Those who are constituted of black bile are indolent, pusillanimous, sickly (philasthenoi), hesitant and cowardly. ${ }^{69}$

What allows us to unite these three texts is the use of the rare Greek adjective philasthenoi, 'sickly', which is not attested elsewhere. On this basis, the resemblance seems very clear. The three descriptions carry the same triad of adjectives ('indolent', 'pusillanimous' and 'sickly'), which suggests, despite their apparently diverse origin (one being anonymous, the other attributed to Hippocrates and the third to John of Damascus), that they go back to a common model that discusses the four temperaments and presents the melancholic temperament as a sickly temperament, characterised by indolence and cowardice.

In this presentation of the melancholic temperament, cowardice might correspond to one of the two feelings characteristic of the melancholic affection in accordance with Hippocrates' Aphorisms. Surprisingly, we find no mention of the second characteristic sentiment, despondency (athumiê), giving the impression that in this group of texts the characterisation of the melancholic temperament is independent from the symptom of the affliction called melancholy. This is what is said in the first group.

We come now to the second group. It includes two Latin texts known to Klibansky (Vindician's Letter and pseudo-Soranus, whose date and relationship, as we saw, still need to be confirmed). To these we must add two Greek texts that I have discovered. The most important in the history of melancholy is a small treatise attributed to Hippocrates called On the Pulse and the Human Temperament because it is, as I have shown elsewhere, ${ }^{70}$ the Greek

68 I have filled a lacuna in the manuscript tradition by comparison with two other texts; see J. Jouanna and J.-P. Mahé (2004), quoted p. 572. The re-constructed Greek text reads: oi

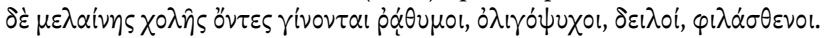

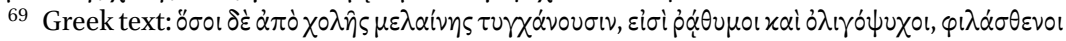

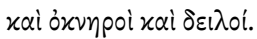

70 I presented a provisional edition of this text in Mélanges A. Hurst (2005), "Un Traité pseudo-hippocratique inédit sur les quatres humeurs (Sur le pouls et sur le tempérament humain)," pp. 449-461; and I have studied in detail the relationship between the Latin and Greek text, which actually comprises two versions, in "La Théorie des quatre humeurs et des quatres tempéraments dans la tradition latine (Vindicien, Pseudo-Soranos) et une source grecque retrouvée," Revue des Etudes Grecques 118, 2005, pp. 138-167. 
model for the Latin letter of Vindician, an important source for the diffusion of the theory of the four humours and the four temperaments in the Latin Middle Ages, as Klibansky points out. The second is a longer treatise called On the Formation of Man. ${ }^{71}$

Here is the melancholic temperament in these four texts:

A. Vindician's Letter: "Black bile makes men cunning, angry, miserly, fearful, sad, lethargic, envious, and frequently having black scars on their feet. ${ }^{72}$

B. Pseudo-Soranus, Isagoge Saluberrima: "Black bile makes men cunning, miserly and perfidious, sad, lethargic, envious and fearful.".73

C. Hippocrates, On the Pulse and the Human Temperament: Version A, ed. Jouanna in Mélanges Hurst, 2005, pp. 449-461: "Black bile makes man completely treacherous, very worried, overwhelmed and very lethargic." ${ }^{74}$

Version B unedited (in Par. gr. 2494): "Black bile (makes man) treacherous, full of anger, constantly worried; it makes people very lethargic and normally with serous fluid in their feet." 75

D. Hippocrates, On the Formation of Man, ch. 8 (the melancholic temperament); ed. Jouanna in Atti del V Colloquio internazionale sull'ecdotica dei testi medici, Napoli 1-2 ottobre 2004, Naples, 2006, p. 315.

1. And if it is the seventh, eighth, or ninth hour of the day or night that the seed is retained in the womb and it uses these three hours for its transformation, $\langle$ such a mixture $\rangle$ will be cold and dry, because these hours of the day and night $\langle$ are cold and dry〉. There is a great quantity of black bile. For black bile abounds in these hours.

2. And the child formed is tinted black. Its hair and eyes are black. Also its whole body. Its vessels are fine and hidden. And there is an

${ }^{71}$ For the edition of this treatise, see J. Jouanna, "Un Traité inédit attribué à Hippocrate, Sur la formation de l'homme: editio princeps," in V. Boudon-Millot, A. Garzya, J. Jouanna and A. Roselli (ed.), I testi medici greci: tradizion e ecdotica, Atti del Ve Convegno internazionale (Naples, 30 sept.-2 oct. 2004), Naples, 2006, pp. 273-319.

${ }^{72}$ Latin text: Cholera nigra facit homines subdolos cum iracundia, avaros, timidos, tristes, somniculosos, invidiosos, frequenter habentes cicatrices nigras in pedibus.

${ }^{73}$ Latin text: Cholera nigra facit subdolos, avaros et perfidos, tristes, somniculosos, invidiosos et timidos.

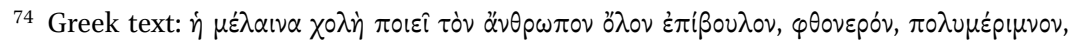

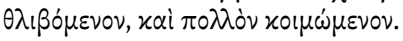

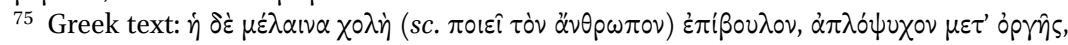

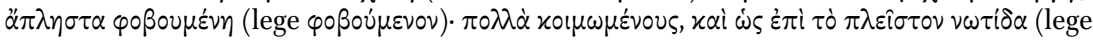

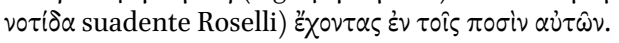


abundance of black bile within it, which makes man a plotter, irritable, timid, overwhelmed, sleepy, envious. ${ }^{76}$

3. He has respiratory difficulties and heaviness of the knees. The bones in his feet hurt. He has colics. He is struck with dysury. He has colics in his lower stomach. His urine is red and troubled. He does not desire food as food, but it becomes like vinegar during digestion. When he vomits food, the humour in it is excessively black. He also has a wild (?) spirit. When phrenitis occurs, lethargy and pains; from inspired (?) states and phrenetic states; strangury ... within. These are the disease of the body of man when there is abundant black bile.

Late medical texts are characteristically malleable, which we can observe thanks to the two quite different Greek versions found in the same treatise, which served as a model for Vindician. Even without entering into a detailed comparison, we notice that in one or the other, or both, of the Greek versions, we find many of the same nouns defining the melancholic temperament as in Vindician's Latin translation: treachery accompanied by anger, fear, sadness, lethargy, envy. A single characteristic of the Latin version that does not have an equivalent in the Greek version is miserliness.

If we compare these portraits of the melancholic, we notice that the Greek vocabulary of the first group is different and, consequently, that there were different sources. The psychological analysis of the second group is richer, even if based on two main characteristics: fear or cowardice, and indolence or lethargy. Surprisingly, we do not find in the first group one of the fundamental symptoms of melancholy, sadness or depression, which is present in the second. To this we can also add treachery with anger and envy. Thus, the psychological profile is richer in the second group.

The second rediscovered Greek treatise also belongs to the second group, since the sentence on the characterisation of the melancholic temperament (which I have put in italics) is roughly comparable to Vindician's Greek model, even if the adjectives are not in the same order. We find fear and lethargy, depression and also trickery, irritability and envy. ${ }^{77}$ However, this

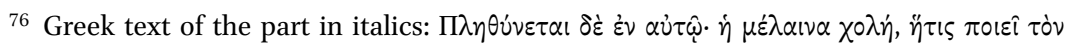

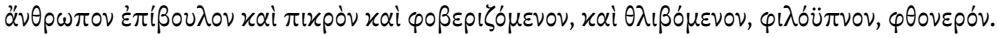

${ }_{77}$ It is particularly similar to version A. We find the same Greek words: treacherous

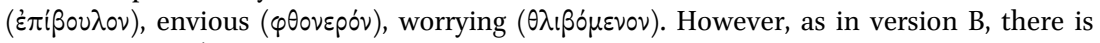
also fear ( $\varphi$ $\left.\beta \varepsilon p ı \zeta{ }^{\mu} \mu \varepsilon v \circ v\right)$. A final characteristic common to Vindician's Letter and his Greek

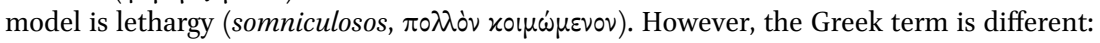


sentence is inserted in a context that differs from the presentation in the other texts in two ways: the explanation of the melancholic temperament by genetics and the addition of a nosology proper to the temperament. ${ }^{78}$

These are the two principal groups of Greek texts on the melancholic temperament. A third group is made up of pseudo-Galen On the Humours and by the treatise Nature of Man by Meletius the monk. The two treatises offer a short comparable discussion of the effect of the predominance of the four humours. The two passages were compared by Klibansky. ${ }^{79}$ Here are the two texts, quoted this time not by the single extract on the melancholic temperament, but by their discussion of the four temperaments:

A. Meletius, De natura hominis (ed. Cramer, 130, pp. 23-26). Extract: influence of the four humours on the soul.

1. When blood dominates, it makes the soul happier

2. When it is yellow bile, this makes the soul more passionate and bold

3. When it is black bile, this makes the soul more majestic and vigorous $^{80}$

4. When it is phlegm, this makes the soul lazier and more stubborn.

B. Pseudo-Galen, On the Humours, 19,492 f. K. Extract: influence of the four humours on the soul.

The humours determine the habits of the soul

it is $\varphi \backslash \lambda \operatorname{lo}^{\mathrm{u}} \pi \nu \circ v$, 'someone who loves sleep'. No doubt this moral analysis of the melancholic temperament goes back to the same common model as the Greek model of Vindician's Letter. However, we find a new adjective: $\pi$ ixpóv, 'irritable'. It could correspond to the iracundia of Vindician's Letter and to the oprn' of version B of its model, the treatise On the Pulse and the Human Temperament.

${ }^{78}$ Using the theory of the predominance of each of the four humours according to the four periods of the day and night, the author explains the formation of the four temperaments according to the hour of conception. If conception takes place at a time when black bile dominates, a child will be born with a temperament corresponding to that humour, and so on. I do not know any parallel to this theory. Surprisingly, in the discussion on illnesses appropriate to the temperament in which black bile dominates, neither melancholy, nor the two other illnesses related to melancholy (epilepsy and madness), appear. Thus, the theory of the temperaments in Greek medicine in Late Antiquity seems to function largely independently from the pathology of melancholy.

${ }^{79}$ Klibansky (footnote 1), p. 61, footnote 98, sees an influence of pseudo-Galen on Meletius the monk. However, the solution is not as simple as this. How do we explain readings of Meletius that are not scribal errors? It might relate to a common source with variants. With the possible connection between Meletius the monk and the Venerable Bede on the description of melancholics, Meletius deserves to figure in Klibansky's table, pp. 116-117. In any case, the resemblances between pseudo-Galen and Meletius are not due to chance. The pair of adjectives qualifying bilious people are not found elsewhere in Greek literature; see J. Jouanna and J.P. Mahé (2004), quoted p. 574.

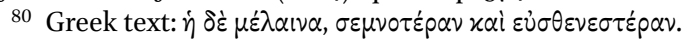


1. Blood makes the soul more joyful

2. Yellow bile makes the soul angrier, bolder or more passionate or both.

3. Phlegm makes the soul lazier and sillier.

4. Black bile makes the soul angrier and insolent. ${ }^{81}$

Regarding the psychological features of the temperaments in which blood, yellow bile or phlegm dominate, Meletius the monk and pseudo-Galen display some agreement. The common terms are written in italics. Conversely, the melancholic temperament has no term in common. Neither is there any connection between the contents, because the portrait in Meletius is laudatory, whilst in pseudo-Galen it is critical. Is this by chance or is it a sign that the melancholic temperament is more fluctuating than others?

Meletius the monk seems isolated in the Greek tradition by speaking of the "majestic" soul of melancholic temperaments. Yet we find a parallel in the Latin tradition. Bede qualifies melancholics as "firm, serious and of a calm character" (stabilis, graves, compositos moribus), ${ }^{82}$ and the Greek semnotês and the Latin gravitas refer to similar concepts. This gives an idea of the complexity of the representation of the melancholic temperament already in the Greek medical tradition. Generally qualified by disparaging terms, without there being a consensus on these nouns, it is favourably described in a very different way in Meletius' De Natura hominis. This case is so far unique in the Greek medical tradition.

However, this final period of Greek medicine is still badly known and further discoveries are still possible. Indeed, it is possible that Vindician's Letter may not be the only Latin treatise on the four humours and the four temperaments translated directly from Greek. The small Latin work On the Four Humours, attributed to the oldest period of the School of Salerno, presents a discussion on the four temperaments which is also associated to what I have termed the second group. Here is the description it gives of the melancholic temperament: "Black bile makes man suddenly irritable, miserly, greedy, sad, lethargic and envious." ${ }^{83}$ Klibansky, having noted the connection with Vindician's Letter, thinks that the treatise is formed of this Letter, augmented with various additions. However, the work

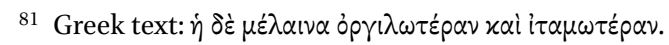

82 Bede, De temporum ratione, ch. 35, ed. C.W. Jones, 1977, p. 392: "Nigra bilis stabilis, graves, compositos moribus dolososque facit."

83 Latin text: "Colera nigra facit hominem subito iracundum, avarum, cupidum, tristem, somnolentum et invidum." 
is distinguished from the Letter by a part of its vocabulary and by certain significant variations; moreover, it preserves a trace of a Greek word. ${ }^{84}$ Thus, it could be another Latin translation made from another Greek model that is yet to be found.

To illustrate the fact that the complexity will only increase following the transition from the Greek to the Latin tradition, I take here as an example what became the portrait of melancholy within the tradition of the School of Salerno in the thirteenth century. ${ }^{85}$ Here is the outline from the Flos medicina:

Melancholics

We now turn to describe the powers of black bile,

Which makes men sad, poor, and little-speaking.

They stay up late to study and their mind is not given to sleep,

They persevere in their goals and think nothing to be certain for them.

He is envious, sad, greedy, with a tenacious right hand.

$\mathrm{He}$ is not without experience of trickery, is timid and has a muddy colour. ${ }^{86}$

${ }^{84}$ The Latin work, found in Laurentianus lat. LXXIII, 1 (A.M. Bandini, Catalogus codicum latinorum Bibliothecae Mediceae Laurentianae, 1774-1777, t. II, p. 406) was edited by S. de Renzi in his Collectio Salernitana, II, pp. 411-412 and hypothetically attributed to Johannes Monachus, a student of Constantine the African. Klibansky (quoted in footnote 1), p. 172, footnote 119, declares that "the text is Vindician's Letter, augmented by various additions." I cannot compare the two texts here in detail, but we should note the presence of a Greek word at the end of the On the Four Humours in a discussion on phlebotomy which is absent from Vindician's Letter: "lyptusma" (read $\lambda \dot{\varepsilon} \pi \tau v \sigma \mu \alpha$ ?, a neuter noun not attested instead of the masculine $\lambda \dot{\varepsilon} \pi \tau \cup \sigma \mu \circ \varsigma$ ), translated by idest lassitudo vel debilitatio stomachi. For the rest, an important variant seems to show that the work cannot be derived from Vindician's Latin translation: in the rubric on the places of humours, Vindician's Letter says that phlegm dominates "in part of the head and in part of the bladder," whilst in this work it is said that it dominates "in part of the bladder and in part of the chest." This reading ("in the chest") is attested precisely in the two Greek treatises I discovered; see J. Jouanna (quoted footnote 71), p. 292 and footnote 32. Thus, it is directly from a Greek text, and not through the intermediary of the Latin tradition of Vindician, that the work On the Four Humours took this reading. Although the ultimate foundation of the text might be Greek, it used an Arabic source. Indeed, at the start it refers, in a definition of health and illness, to something not found in Vindician's Letter, "to the seventh book epodon [sic]." By epodon we should understand, as Anna Maria Ieraci Bio suggested to me, the Ephodia of ibn al Gazzar (end of the tenth century). Thus, whilst the foundations of the text are Greek, as Vindician's Letter, this does not stop the author from making reference to an Arabic authority as well. If it does concern a reference to the Viaticum of ibn al Gazzar (c. 878-980), the redaction of the work is posterior to it. Since the Viaticum was translated into Latin by Constantine the African, we can legitimately connect this text to the School of Salerno, as S. de Renzi did.

${ }^{85}$ On the spread of the doctrine of the four temperaments in the School of Salerno in the twelfth and the thirteenth centuries, see Klibansky (quoted in footnote 1), p. $182 \mathrm{f}$.

${ }^{86}$ Flos medicinae, ed. de Renzi, Collectio Salernitana I, Flos medicinae 4, 2, 4, reviewed by 
In this outline, we can recognise several of the characteristics mentioned in the second group, that of the Greek tradition which is the origin of Vindician's Letter: sadness, envy, greed, trickery, fear. ${ }^{87}$ Thus, the medical tradition of Salerno seems, like Vindician's Letter, to have come from the Greek tradition. However, there is a noticeable difference relating to sleep. Whilst the two new Greek treatises, like Vindician's Letter and the Latin work On the Four Humours, when it is discussed, describe melancholics as sleepy, the Flos medicinae, on the other hand, presents them as intellectuals whose spirit is not given to sleep. ${ }^{88}$

The divergence is not due to chance, since it fits within a systematic contrast between the melancholic and phlegmatic temperament. In the texts from the second group, there was an antithesis between the melancholic, who was sleepy, and the phlegmatic, who was lively. It is exactly the opposite in the Flos medicinae. ${ }^{89}$ The evolution of the image of the melancholic is considerable.

Should we see the influence of Problem 30.1 in this more positive presentation of the melancholic as an intellectual? Probably.

Thus, the Aristotelian tradition, if less present in the Greek medical tradition, reappeared in the medieval period in the Latin tradition of the

Ch. Daremberg in Ch. Meaux Saint-Marc, L'École de Salerne, Paris, Ballière, 188o, p. 171. Latin text:

Melancholici:

Restat adhuc cholera virtutes dicere nigrae;

Quae reddit tristes, pravos, perpauca loquentes;

Hi vigilant studio, nec mens est dedita somno;

Servant propositum, sibi nil reputant fore tutum;

Invidus et tristis, cupidus, dextraeque tenacis,

Non expers fraudis, timidus, luteique coloris.

${ }^{87}$ Certain words are the same as those in Vindician's Letter (tristis, timidus, invidus vel invidiosus), others are synonymous (Vindician: avarus; Flos medicinae: cupidus. Vindician: subdolosus; Flos medicinae: Non expers fraudis).

88 Phlegmatics are described as sleepy in the Flos medicinae: "Hic somnolentus." Klibansky (quoted in footnote 1), p. 182, highlights the same absence of the noun 'sleepy' for the melancholic in the Flores diaetarum, a work dating from the twelfth century. Should we see an evolution within the School of Salerno between the treatise On the Four Humours (tenth/eleventh century) and the texts produced in the twelfth and thirteenth centuries?

${ }^{89}$ In Bede (in 752), the phlegmatic is already called somnolentus. However, in this description of the melancholic (quoted in footnote 82), nothing is said on sleep or being awake. This is probably also the case in the first version of the Flos medicinae, where only two verses were dedicated to each temperament (here the two last verses for melancholics). The addition of the four first verses provides the outline of the melancholic with its intellectual dimension. However, already in the first version the phlegmatic was qualified as somnolentus, which contradicts the older work On the Four Humours, in which the phlegmatic is lively ("Phlegma facit hominem vigilantem"). 
theory of the temperaments, coming to be attached to the Greek medical tradition of Late Antiquity, which continues to claim to follow Hippocrates, whilst the foundation treatise of the whole theory, the Nature of Man, seems forgotten. 